\title{
Ellipsis
}

2014

\section{Venetian Ghetto}

Elizabeth Lynch

Follow this and additional works at: https://scholarworks.uno.edu/ellipsis

Part of the Fine Arts Commons, and the Photography Commons

\section{Recommended Citation}

Lynch, Elizabeth (2014) "Venetian Ghetto," Ellipsis: Vol. 41 , Article 10.

DOI: https://doi.org/10.46428/ejail.41.10

Available at: https://scholarworks.uno.edu/ellipsis/vol41/iss1/10

This Photography is brought to you for free and open access by the Department of English and Foreign Languages at ScholarWorks@UNO. It has been accepted for inclusion in Ellipsis by an authorized editor of

ScholarWorks@UNO.For more information, please contact scholarworks@uno.edu. 


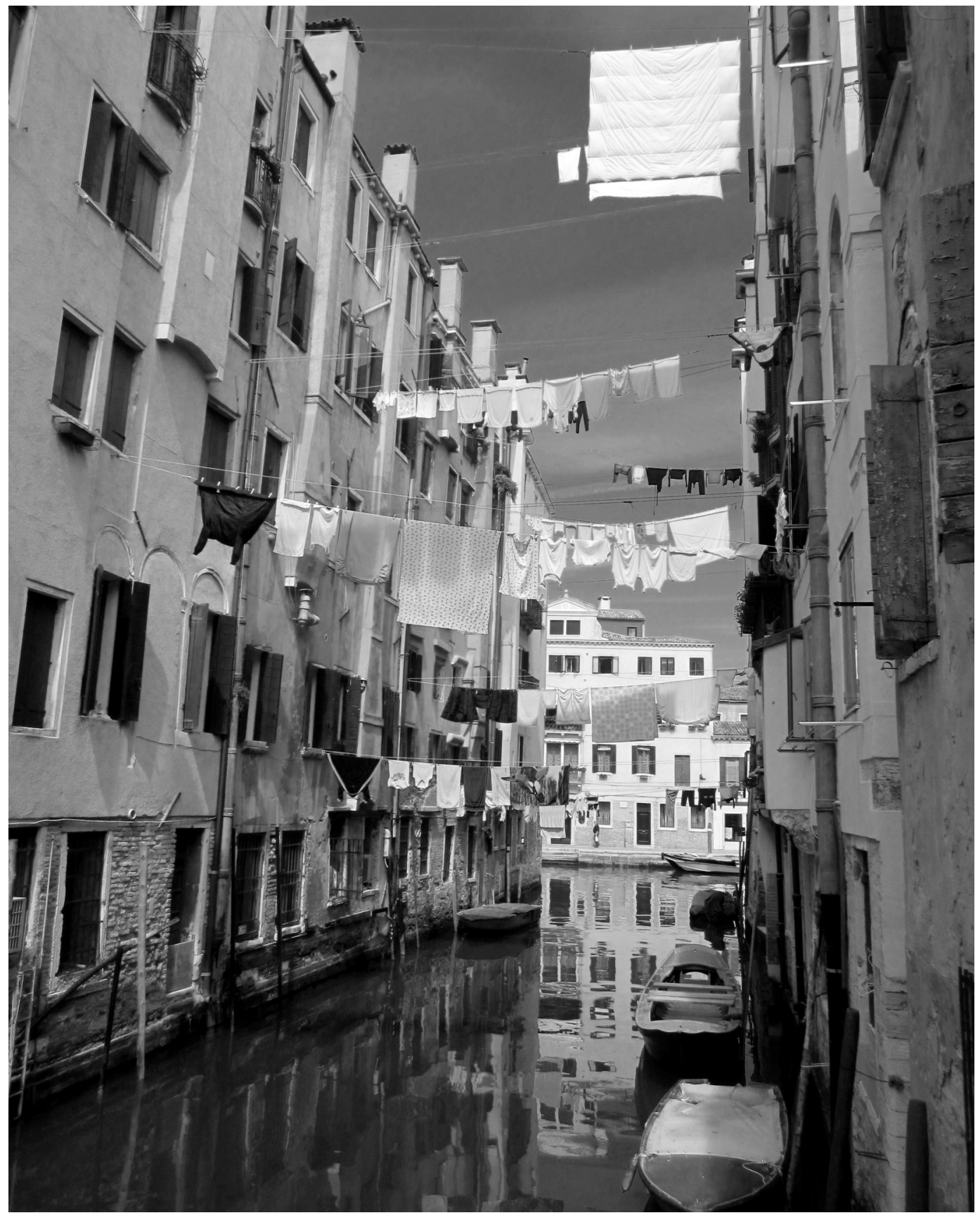

